\title{
Peran Ketua Rukun Warga Sebagai Servant Leader dan Masyarakat untuk Keberhasilan Mendapatkan Proyek Pembangunan Infrastruktur
}

\author{
Nining Purwatmini 1), Shalahudin 2), Hari Sapto Yudiarso3) \\ 1,2,3) Program Studi Manajemen Administrasi, Fakultas Bisnis, \\ Universitas Bina Insani Bekasi, Indonesia \\ Diterima Februari, 2020; Disetujui April, 2020; Dipublikasikan Juni, 2020
}

\begin{abstract}
Abstrak
Penelitian ini bertujuan untuk melihat peran Ketua Rukun Warga (Ketua RW) dan partisipasi masyarakat terhadap keberhasilan mendapatkan usulan dana proyek pembangunan yang berbasis pada kebutuhan nyata masyarakat. Karena, pada era reformasi telah terjadi perubahan model pengajuan usulan proyek pembangunan. Jika sebelumnya pembangunan proyek menerapkan pola dari atas ke bawah (dana dikucurkan oleh Pemerintah Kota), maka saat ini pola pengajuan usulan pembangunan proyek dari bawah ke atas. Data penelitian ini didapat dari angket yang diisi oleh 350 Kepala Keluarga, di lingkungan RW 09, Kelurahan Kranji, Kecamatan Bekasi Barat, Kota Bekasi. Hasil 204 angket kembali diolah menggunakan metode analisis secara kuantitatif berupa regresi, pengolahan dengan bantuan SPSS ver. 24. Hasil uji statistik terhadap angket, menunjukkan bahwa keberhasilan mendapatkan dana proyek perbaikan sarana lingkungan sangat kuat di tentukan oleh gaya kepemimpinan "servant leader" yang diterapkan oleh Ketua RW 09 (menunjukkan koefisien korelasi sebesar 0.833), dibandingkan dengan "partisipasi masyarakat" (koefisien korelasi sebesar 0.635). Dalam hal ini, nampak bahwa perubahan model pengajuan dana pembangunan fasilitas, di Kota Bekasi, dipengaruhi oleh penerapan kepemimpinan servant leadership dan partisipasi masyarakat.
\end{abstract}

Kata Kunci: Peran Ketua RW, Hibah, Partisipasi Masyarakat, Usulan Pembangunan

\section{Abstract}

This study aims to look at the role of the Chairman of the Rukun Warga (RW Chairman) and community participation in the success of getting proposed development project funds based on the real needs of the community. Because, in the reform era there has been a change in the model of proposing development projects. If previously the project development applied a top-down pattern (funds were disbursed by the City Government), the current pattern of submitting project development proposals is from the bottom up. The research data was obtained from a questionnaire filled out by 350 families, in RW 09, Kranji Sub-District, West Bekasi District, Bekasi City. The results of 204 questionnaires were re-processed using quantitative analysis methods in the form of regression, processing with the help of SPSS ver. 24. The results of statistical tests on the questionnaire, showed that the success of getting funding for environmental infrastructure improvement projects was very strong determined by the leadership style of "servant leader" applied by the Chairman of RW 09 (showing a correlation coefficient of 0.833), compared to "community participation" (coefficient correlation of 0.635). In this case, it appears that changes in the model for submitting funds for facility construction, in Bekasi City, are influenced by the application of servant leadership and community participation.

Keywords: The role of RW Chairperson, grants, community participation, development proposal.

How to Cite: Purwatmini, N; Sholahuddin; Yudiarso, H. S. (2020). Peran Ketua Rukun Warga Sebagai Servant Leader dan Masyarakat Untuk Keberhasilan Mendapatkan Proyek Pembangunan Infrastruktur. PUBLIKAUMA: Jurnal Administrasi Publik UMA, 8 (1): 50-56

\begin{tabular}{lr}
\hline$*$ Corresponding author: & ISSN 2549-9165 (Print) \\
niningbinainsani@binainsani.ac.id & ISSN 2580-2011 (Online)
\end{tabular}




\section{PENDAHULUAN}

Perubahan kebijakan pengajuan usulan proyek pembangunan di pemerintah Kota Bekasi saat ini menggunakan pola dari bawah ke atas, memberikan kesempatan seluas-luasnya peran aktif masyarakat untuk membangun lingkungannya. Melalui pola kebijakan usulan pembangunan proyek pembangunan dari bawah ke atas, tentunya hasil pembangunan tersebut sesuai dengan kebutuhan nyata masyarakat di lingkungan tersebut.

Keterlibatan masyarakat mulai dari proses awal usulan pembangunan proyek diharapkan juga pengawasan pelaksanaan pembangunan proyek, akan lebih efektif karena masyarakat akan terlibat secara aktif.

Usulan proyek pembanguanan yang dapat diajukan masyarakat dapat berupa pembanguanan jalan lingkungan, perbaikan fasilitas sosial atau rumah ibadah, pengadaan taman bermain anakanak dan sebagainya. Mekanisme pengajuan usulan pembangunan proyek pembangunan diawali dengan pengajuan usulan masyarakat dari setiap Rukun Tetangga (RT), melalui rapat warga dari setiap RT, lalu hasil dari pembahasan dari tingkat RT diajukan ke tingkat Rukun Warga (RW). Kemudian pada tingkat RW, dipimpin oleh Ketua RW diadakan rapat antar Ketua RT untuk memilih usulanusulan proyek pembanguanan yang menjadi prioritas kebutuhan warga di lingkungan tersebut. Setelah didapatkan hasil kesepakatan atas usulan-usulan proyek pembangunan yang menjadi prioritas, kemudian Ketua RW menyampaikan hasil tersebut ke tingkat Kelurahan. Keberhasilan RW 09 Kelurahan Kranji dalam mendapatkan 11 (sebelas) proyek usulan pembangunan untuk tahun anggaran 2015, merupakan sebuah prestasi yang perlu menjadi model bagi RW lainnya. Dengan adanya model pengajuan usulan proyek pembangunan seperti yang sudah dilakukan oleh warga RW 09 ini, kedepan diharapkan tujuan dari perubahan model pengajuan dana proyek pembangunan yang dilakukan oleh pemerintah, akan bisa lebih banyak lagi penggunaan dana tepat guna dan tepat sasaran bagi masyarakat. "Servant leadership" atau kepemimpinan pelayanan, merupakan konsep kepemimpinan yang awalnya (pada tahun 1970) diperkenalkan sebagai kepemimpinan etis oleh Robert K. Greenleaf (Greenleaf, 2002). Kepemimpinan tipe ini sesuai untuk pemimpin dalam organisasi perusahaan maupun organisasi sosial.

Penerapan budaya organisasi yang menggunakan gaya kepemimpinan pelayan menunjukkan bahwa pemimpin diharapkan dapat menerapkan manajemen konflik sesuai dengan keadaan di organisasi.

Penelitian membuktikan adanya pengaruh budaya organisasi dengan kepemimpinan pelayan (Widyastuti, 2016). Gaya kepemimpinan yang digunakan adalah gaya kepemimpinan pelayan serta manajemen konflik di PT. Indonesia Power - UBH di Jakarta.

Konfirmasi mengenai keterampilan yang harus dimiliki oleh seorang pemimpin pelayan (servant leader), diwakili oleh 20 (dua puluh) pernyataan. Kepemimpinan melayani (servant leadership) merupakan persepsi karyawan atau anggota komunitas. Persepsi mengenai tipe atau gaya kepemimpinan yang dimiliki oleh seorang kepala bagian atau ketua komunitas. Gaya kepemimpinan mencakup, memiliki kerendahan hati, memiliki gambaran masa depan yang memberikan motivasi dalam mencapai gambaran masa depan.

Selain itu, gaya kepemimpinan melayani memiliki kepercayaan serta keyakinan terhadap para karyawannya, mampu melayani atau memahami karyawannya. Melalui sikap, perilaku, nilai-nilai yang baik dalam kehidupan 
sehari-harinya, pemimpin akan mempercayai kekuatan yang dimiliki oleh para pegawai atau karyawannya. Pemimpin hendaknya juga mendengarkan secara efektif, sehingga membuat karyawan merasa dihargai, serta memberikan motivasi atau kekuatan kepada para karyawanya (Windiyani, 2016).

Selain itu, penelitian lain (Aji, 2015) ini terbukti bahwa terdapat pengaruh positif dan signifikan, ketika seorang pemimpin menerapkan servant leadership. Dampak secara langsung terhadap kinerja, terutama ketika di dalam penerapannya, pemimpin menekankan pada pendekatan sosial (untuk berbagai hal yang sifatnya bukan teknis pekerjaan) dengan karyawannya.

Partisipasi, dalam suatu komunitas masyarakat, menyatakan bahwa komunitas tersebut berupaya untuk memecahkan masalah yang mereka hadapi berdasarkan kajian yang mereka lakukan terhadap masalah tersebut, lalu menentukan pilihan terhadap berbagai alternatif pemecahan masalah, yang paling sesuai dengan kondisi dan kemampuan komunitas tersebut (Sumaryadi, 2010). Selain itu (Supriadi, 2001) menyatakan bahwa partisipasi merupakan kegiatan

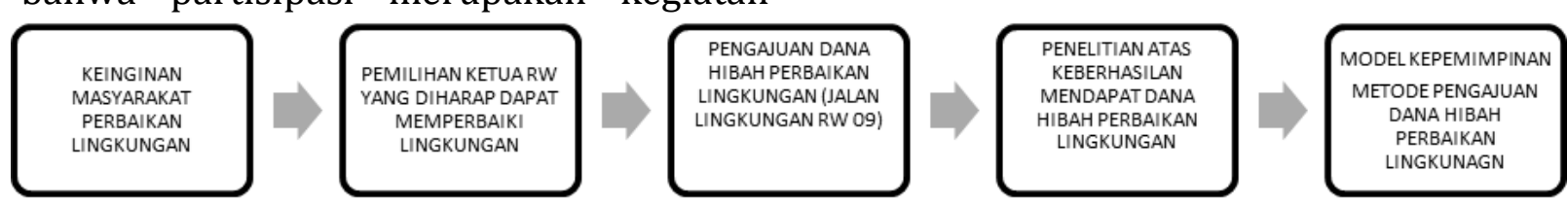

Sumber: pengolahan dalam penelitian

Gambar 1: Alur proses kegiatan yang diteliti

Untuk memperoleh data akurat yang dapat dipercaya kebenarannya, dan relevan terhadap masalah yang diteliti, maka pengumpulan data dilakukan dengan penyebaran angket kepada 350 Kepala keluarga di lingkungan RW 09 Keluarahan Kranji. Kemudian dilakukan wawancara untuk memastikan beberapa pernyataan dan temuan dari hasil angket.

Mengacu pada jumlah populasi 485 kepala keluarga, dengan tingkat kepercayaan yang dilakukan oleh sekelompok orang di dalam sebuah komunitas, guna membuat keputusan, dalam hal ini, keputusan tersebut dibuat berdasarkan saran, aspirasi dan pendapat setiap anggota komunitas di dalam kelompok tersebut.

(Uphoff, 1980) menyampaikan bahwa terdapat 4 (empat) jenis partisipasi, yaitu pertama, partisipasi dalam pembuatan keputusan. Partisipasi kedua, partisipasi ketika melaksanakan kegiatan, sedangkan yang ketiga adalah partisipasi dalam memanfaatkan hasil keputusan, pada gilirannya adalah partisipasi dalam melakukan evaluasi setiap kegiatan yang dilakuakan berdasarkan keputusan yang dibuat bersama.

\section{METODE PENELITIAN}

Metode yang digunakan dalam penelitian ini adalah metode kuantitatif inferensial, menurut (Sugiyono, 2013), penelitian kuantitatif inferensial mencoba melihat hubungan atau kausal sebab akibat, dalam hal ini adalah hubungan peran Ketua RW dan partisipasi masyarakat terhadap keberhasilan mendapatkan dana proyek pembangunan berdasarkan data yang telah dikumpulkan.

Penelitian di lakukan berdasarkan alur proses berikut: 


$$
\begin{aligned}
& n=\frac{N}{N\left(1+e^{2}\right)} \\
& \mathrm{n}=\text { jumlah sampel }(219 \text { kepala keluarga }) \\
& \mathrm{N}=\text { jumlah populasi }(485 \text { kepala } \\
& \mathrm{e}=\text { keluarga) } \\
& \mathrm{e}=\text { marjin error }(5 \%) .
\end{aligned}
$$

Angket yang telah diisi, kembali sebanyak 204 angket, dan ini cukup memadai jika mengacu pada hasil perhitungan rumus Slovin, sebanyak 219 sampel. Tidak terdapat perbedaan yang signifikan, baik antara sampel pria dan wanita, maupun antar kelompok usia.

Kuisioner yang disebarkan kepada 350 kepala keluarga berisikan pertanyaan atau pernyataan yang menunjukkan variabel "keberhasilan mendapatkan dana hibah pembangunan" sebanyak 9 (sembilan) pernyataan/ pertanyaan. Untuk variabel "peran serta masyarakat" dikonfirmasi melalui 8 (delapan) pertanyaan/ pernyataan.

\section{HASIL DAN PEMBAHASAN}

Peran dan Fungsi Ketua RW, sebagai pemimpin pada unit terkecil masyarakat di Indonesia, diatur di dalam aturan tentang "Penataan Lembaga Ketahanan Masyarakat Desa" atau Sebutan lain, diatur mengenai keberadaan organisasi dan kepengurusan Rukun Tetangga dan Rukun Warga. Penataan ini dituangkan dalam Keputusan Presiden Republik Indonesia Nomor 49 Tahun 2001.

Kemudian Pemerintah Daerah menetapkan peraturan yang berlaku di daerah masing-masing, sesuai dengan situasi dan kondisi masing-masing daerah. Peraturan ini memberikan petunjuk tentang "Pedoman Pembentukan dan Tata Cara pemilihan pengurus Rukun Warga (RW)", selain itu masing-masing daerah mengatur tentang hak dan kewajiban pengurus RW, tugas dan fungsi Ketua, Sekretaris dan perangkat RW, serta masa bakti kepengurusan RW. Dalam hal Peratuiran Daerah mengatur persyaratan yang harus dipenuhi oleh seorang warga, agar memenuhi kriteria sebagai pengurus, baik RW maupun pengurus RT. Hal lain yang dituangkan di dalam peraturan daerah tentang "Penataan Lembaga Ketahanan Masyarakat Desa", adalah musyawarah antar anggota untuk membuat keputusan yang berdampak kepada kondisi seluruh warga masyarakat (komunitas), aturan tentang keuangan dan kekayaan RT dan RW.

Tugas pokok ketua RW menurut peraturan daerah kota Bekasi no. 5 tahun 2015 tentang pedoman pembentukan Rukun Warga (RW), Rukun Tetangga (RT), dan Lembaga Pemberdayaan Masyarakat (LPM) Kota Bekasi pada Bab III pasal 4, pasal 5 dan pasal 6 adalah sebagai berikut, tugas pokok ketua RW sebagai pelayanan warga, sebagai kepanjangan tangan dan tanggung jawab Pemerintah Daerah, menjamin terciptanya kondisi kehidupan rukun di kalangan warga, serta menjamin terciptanya rasa persatuan dan kesatuan antar warga pada gilirannya menggerakkan warga untuk bergotong royong dalam melaksanakan pembangunan guna kemaslahatan lingkungannya. Selain memiliki tugas pokok, ketua RW berfungsi untuk mengkoordinasian antar warga, melaksanakan fungsi sebagai penghubung antar warga dengan Pemerintah Daerah, serta penanganan masalah-masalah sosial masyarakat yang dihadapi warga.

Mengacu pada tugas pokok dan fungsi ketua RW tersebut, maka keterampuilan servant leader yang diterapkan oleh ketua RW 09, Kelurahan Kranji, Kota Bekasi. Keterampilan mendengarkan, ketua RW sebagai servant leader di unit terendah pemerintahan Indonesia, nampak pada setiap urun rembug warga, ketua RW mendengarkan segala hal yang menjadi aspirasi masyarakat, utamanya ketika mengajukan dana hibah pembangunan kepada Pemerintah Daerah Kota Bekasi. Ketika harus berempati, ketua RW merasakan gangguan bagi para warga, yang disebabkan oleh rusaknya fasilitas lingkungan, dalam hal ini adalah rusaknya jalan di lingkungan RW 09 Kelurahan Kranji, Kota Bekasi, namun tak kunjung diperbaiki oleh Pemerintah Kota Bekasi. Oleh karenanya, keterampilan healing oleh Ketua RW 09, dilakukan dengan mengundang warga, melakukan rapat tingkat kelompok kecil untuk urun rembug, lalu rapat tingkat ketua RT, guna mencari pemecahan masalah dan melakukan urun rembug tahapan dan kegiatan pemecahan masalah tersebut. Rapat ini menunjukkan bahwa Ketua RW 09 peduli pada kebutuhan masyarakat agar masyarakat merasa nyaman dan tidak terganggu, dengan 
ketersediaan sarana lingkungan yang memadai.

Persuasive yaitu pendekatan secara halus yang dilakukan oleh ketua RW 09 kelurahan Kranji sebagai servant leader membuat warga masyarakat RW 09 merasa nyaman, sehingga pada gilirannya, anggota komunitas dengan sukarela turut ambil bagian dalam setiap kegiatan yang diselenggarakan oleh pengurus RW 09. Ketika anggota aktif dalam setiap kegiatan, maka akan mudah juga bagi pengusru RW 09 untuk menyusun rencana kerja termasuk rencana pengajuan hibah kepada Pemerintah Kota Bekasi, guna perbaikan sarana lingkungan RW 09, diharapkan berdampak pada kenayaman bagi warga RW 09.

Kenyamanan warga menuju kepada produktivitas warga dalam berkegiatan, baik secara sosial maupun ekonomi. Penyusunan rencana kerja oleh Ketua RW bersama warga RW, didasarkan pada foresight, dalam hal ini penyusunan rencana kerja berdasarkan kenyataan masa kini serta keinginan kemajuan di masa depan, sekaligus mengantisipasi berbagai masalah potensial yang akan muncul, jika keputusan diterapkan. Berbasis pada pengalaman sebagai pengurus RT di lingkungan RW 09, berbagai keputusan yang dibuat oleh ketua RW 09, didukung oleh warga, karena dipercaya akan sepenuhnya mendukung pengembangan kondisi warga dan lingkungannya.

Stewardship and commitment itulah yang menjadi dasar pengembangan warga sebagai komunitas (building community) merupakan komitmen dari seorang servant leader untuk melayani semua fihak di dalam komunitasnya dalam keadaan saling percaya serta lebih mengutamakan keterbukaan. Halhal tersebut (stewardship and commitment to build the community) menjadikan pengembangan komunitas di lingkungan RW 09 tercapai. Terbukti dengan diloloskannya hibah perbaikan sarana lingkungan. Penerapan keterampilan servant leader oleh Ketua RW 09 , terbukti dari hasil angket yang disebarkan ke warga RW 09.
Pengujian terhadap variabel "servant leader", menunjukkan nilai Cornbach Alfa sebesar 0,643 , dinilai data cukup valid.

Tabel 1. Uji Realibilitas Bagi Variabel "Servant Leader"

Reliabilitas data "servant leader"

Cornbach alfa Jumlah pertanyaan

0,64320

Sumber : data diolah, 2019

Hasil pengujian terhadap variabel "peran serta masyarakat", menunjukkan nilai Cornbach Alfa sebesar 0, 4i8, dinilai data cukup valid .

Tabel 2. Uji Realibilitas Bagi Variabel "Peran Serta Masyarakat"

\begin{tabular}{cc}
\hline Reliabilitas Data Peran Serta Masyarakat \\
\hline Cornbach Alfa & $\begin{array}{c}\text { Jumlah } \\
\text { Pertanyaan }\end{array}$ \\
\hline 0,418 & 8 \\
\hline
\end{tabular}

Sumber : data diolah, 2019

Berikutnya, hasil pengujian realibilitas terhadap variabel "keberhasilan mendapatkan dana", menunjukkan nilai Cornbach Alfa sebesar 0, 599, dinilai data valid.

Tabel 3. Uji Realibilitas Bagi Variabel "Keberhasilan Mendapatkan Dana Hibah"

Realibilitas Data Keberhasilan Mendapat Dana

\begin{tabular}{cc}
\hline Cornbach Alfa & Jumlah Pertanyaan \\
\hline 0,599 & 9 \\
\hline
\end{tabular}

Sumber : data diolah, 2019

Dari tabel di atas, terlihat besarnya koefisien Cronbach's Alpha (koefisien hitung reliabilitas alpha) setiap variabel besarnya lebih besar dan mendekati 0,60 berarti bahwa pertanyaan (kuesioner) seluruh variabel adalah reliabel. Hanya saja pernytaan tentang peran serta masyarakat, menunjukan "kurang valid". 
Tabel 4. Uji Korelasi Antar Tiga Variabel

\begin{tabular}{ccccc}
\hline \multicolumn{5}{c}{ Korelasi antar tiga variabel } \\
\hline \multirow{3}{*}{$\begin{array}{c}\text { Pearson } \\
\text { Correlati } \begin{array}{c}\text { JK } \\
\text { on }\end{array}\end{array}$} & $\mathrm{JK}$ & 1,000 &, 833 &, 635 \\
\cline { 2 - 5 } & $\mathrm{JSL}$ &, 833 & 1,000 &, 748 \\
\hline \multirow{2}{*}{$\begin{array}{l}\text { Sig. (1- } \\
\text { tailed) }\end{array}$} & $\mathrm{JPM}$ &, 635 &, 748 & 1,000 \\
\cline { 2 - 5 } & $\mathrm{JSL}$ &, 000 &, 000 &, 000 \\
\cline { 2 - 5 } & $\mathrm{JPM}$ &, 000 &, 000 &, 000 \\
\hline \multirow{3}{*}{$\mathrm{N}$} & $\mathrm{JK}$ & 204 & 204 & 204 \\
\cline { 2 - 5 } & $\mathrm{JSL}$ & 204 & 204 & 204 \\
\cline { 2 - 5 } & $\mathrm{JPM}$ & 204 & 204 & 204 \\
\hline
\end{tabular}

Sumber : data diolah, 2019.

$\mathrm{JK}=$ variabel keberhasilan, $\mathrm{JSL}=$ variabel servant leadership, JPM = variabel peran serta masyarakat.

Penelitian menunjukan bahwa penerapan gaya kepemimpinan melayani (servant leadership) oleh Ketua RW 09 Kelurahan Kranji, Bekasi Barat serta partisipasi masyarakat menghasilkan keberhasilan mendapatkan dana pembangunan infrastuktur. Hal ini dijelaskan oleh hasil wawancara dengan para warga RW 09 Kelurahan Kranji, yang mengatakan bahwa mereka telah mendapatkan 11 (sebelas) paket dana pembanguanan dan perbaikan infrastruktur, dari 11 (sebelas) paket proposal yang di ajukan.

\section{SIMPULAN}

Hasil penelitian menunjukan bahwa keterampilan "servant leader" yang dimiliki dan diterapkan dalam memimpin komunitas oleh Ketua RW 09 , kelurhan Kranji, Kecamatan Bekasi Barat sangat berperan dalam mencapai komunitas nyaman dan produktif di lingkungan yang dipimpinnya. Keterampilan ini juga sejalan dengan kebijakan Pemerintah Kota Bekasi, yang menetapkan bahwa pengucuran dana hibah proyek-proyek pembangunan di lingkungan berdasarkan usulan dari kebutuhan masyarakat. Pengajuan proposal dana hibah dilakukan dari mulai tingkat RT kemudian kompilasi oleh RW 09 dan selanjutnya disampaikan ke Kelurahan Kranji akhirnya ke Kecamatan Bekasi Barat. Tingkat keberhasilan RW 09 cukup tinggi, Nampak dari didapatnya sejumlah 11 (sebelas) dana hibah proyek untuk pembanguan dan perbaikan infrastruktur.
Secara statistik dapat disimpulkan bahwa ketika instrumen yang berisi 37 (tiga puluh tujuh) pernyataan, mewakili 3 (tiga) variabel tentang "keberhasilan mendapatkan dana hibah perbaikan infrastruktur/ jalan lingkungan", variabel "partisipasi masyarakat" dan variabel "servant leader" yang diterapkan oleh ketua RW 09 kelurahan Kranji, kecamatan Bekasi Barat, menghasilkan kesimpulan bahwa penerapan "servant leadership" guna menarik peran masyarakat, menunujukkan hasil signifikan (secara statistik ditunjukkan oleh tingkat korelasi yang kuat sebesar 0.833). Peran serta masyarakat meyakinkan pihak pemberi hibah bahwa dana hibah yang dikucurkan, memang digunakan untuk kepentingan lingkungan warga, serta sesuai dengan kebutuhan warga. Pernyataan dalam angket menggali dan mengkonfirmasi karakter ketua RW 09, yang memang secara konsisten menerapkan karakter "servant leadership".

Penerapaan karakter ini mendorong peran serta warga masyarakat dalam semua hal, terutama "urun rembug" guna menyelesaikan masalah yang muncul di kalangan dan di kawasan RW 09 , kelurahan Kranji, Kecamatan Bekasi Barat. "Urun rembug" merupakan bentuk partisipasi masyarakat di lingkungan RW 09 Kelurahan Kranji, baik ketika mencari jalan pemecahan masalah, maupun menyusun proposal guna mendapatkan dana hibah pembangunan dan perbaikan infrastruktur.

\section{UCAPAN TERIMAKASIH}

Terima kasih kepada Warga RT 09 (204 Kepala Keluarga dari tujuh Rukun Warga), Kelurahan Kranji Kecamatan Bekasi Barat, untuk pertisipasi memberikan jawaban pada angket yang telah menjadi dasar pembuatan naskah penelitian ini. Juga terima kasih kepada Kemenristekdikti, untuk pendanaan penelitian ini.

\section{DAFTAR PUSTAKA}

Aji, M. (2015). Pengaruh Servant Leadership Terhadap Kinerja Dengan Burnout Sebagai Variabel Intervening Pada Karyawan PT. Intiroda Makmur Persada Tbk, Tangerang. Doctoral dissertation.

Andreeyan, R. (2014). Studi tentang partisipasi masyarakat dalam pelaksanaan pembangunan di Kelurahan Sambutan 
Kecamatan Sambutuan. Kota Samarinda. . Journal Administrasi Negara (ejournal.an.fisip-unmul.) , 1938-1951.

Block, P. (1993). Stewardship: Choosing service over self-interest. California: Berrett-Koehler

Daerah, P. (2005). Pedoman Pembentukan Rukun Tetangga (RT), Rukun Warga (RW) dan Lembaga Pemberdayaan Masyarakat (LPM). Kota Bekasi: Pemerintah Kota Bekasi.

Dwiningrum, S. I. (2011). Desentralisasi dan Partisipasi Masyarakat dalam Pendidikan. Yogyakarta: Pustaka Pelajar.

Ellen, S. (2017). Slovin's formula for sampling technique.

Ghozali., K. K. (2013). Teknik Penyusunan Skala Likert (Summated Scales) dalam Penelitian Akuntansi dan Bisnis. Fatawa Publishing. Semarang.: Fatawa Publishing. Semarang.

Ginting, R. (2011). Partisipasi Masyarakat dalam Musyawarah Perencanaan Pembangunan (Musrenbang) di Kabupaten Sarolangun. Yogyakarta.: Repository Pascasarjana, Universitas Gadjah Mada.

Greenleaf, R. K. (2002). Servant Leadership, A Journey inti the Legitimate Power \& Greatness. New York: Paulist Press.

Kali, A. (2011). Analisis partisipasi masyarakat terhadap perencanaan dan pembangunan PLTMH di Paneki Desa Pombewe. Kecamatan Biromaru Kabupaten Sigi. Kali, Agustinus. (2011). Analisis partisipasi masyarakat terhadap perencanaan dan pembangunan PLTMH di Jurnal Mektek Tahun XII No. 3.

Kranji, S. E. (2014). Juknis Pelaksanaan Musrenbang. Bekasi: Kelurahan Kranji.

Purnamasari, I. (2007). Studi Partisipasi Masyarakat Dalam Perencanaan Pembangunan di Kecamatan Cibadak. Kabupaten Sukabumi. Semarang: Repository Pascasarjana. Universitas Diponegoro.

RI, D. (2004). Undang-Undang Nomor 25 Tahun 2004 Tentang Sistem Perencanaan Pembangunan Nasional. Jakarta: DPR RI.

RI, D. (2004). Undang-Undang Nomor 32 Tahun 2004 Tentang Pemerintahan Daerah. Jakarta: DPR RI.

Satries, W. I. (2011). Mengukur Tingkat Partisipasi Masyarakat Kota Bekasi Dalam Penyusunan APBD Melalui Pelaksanaan Musrenbang . Jurnal Elektronik Kybernan. Vol. 2 (2), 89130.

Sugiyono. (2013). Metode Penelitian Kuantitatif Kualitatif dan R\&D. Bandung: CV Alfabeta.

Sumaryadi, I. N. (2010). Sosiologi Pemerintahan dari Perspektif Pelayanan, Pemberdayaan, Interaksi dan Sistem Kepemimpinan
Pemerintah Indonesia. Bogor: Ghalia Indonesia.

Supriadi, F. D. (2001). Reformasi Pendidikan Dalam Konteks Otonomi Daerah. Yogya karta: Adicita Karya Nusa.

Uphoff, J. M. (1980). Participation's place in rural development: seeking clarity through specificity. Cornall University: World development.

Widyastuti, T. (2016). Pengaruh Kepemimpinan Pelayan Dan Budaya Organisasi Terhadap Pengelolaan Konflik. Cakrawala-Jurnal Humaniora, 16 (2).

Windiyani, D. A. (2016). Hubungan Kepemimpinan Yang Melayani (Servant Leadership) Dengan Komitmen Organisasi Pada Karyawan Bagian Produksi. Malang: University of Muhammadiyah. 